\title{
GENDER ROLES IN TEFF VALUE CHAIN IN BORECHA DISTRICT OF SOUTH WESTERN ETHIOPIA: HUSBAND AND WIFE COMPARISONS
}

\author{
Sisaynesh Tekalign ${ }^{1}$, Adugna Eneyew $^{1 凶}$, Fikadu Mitiku $^{1}$ \\ ${ }^{1}$ Jimma University College of Agriculture \& Veterinary Medicine, Ethiopia
}

\begin{abstract}
Teff is a highly valuable grain for Ethiopian people in generating income and achieving food security. Using unique cross-sectional data from husbands and wives, descriptive statistics and an econometric model, this paper analyzes gender roles in the teff value chain in south-western Ethiopia. Primary data was collected from 117 farmers, 38 traders and 14 consumers. Findings indicate that women contribute more than their husbands to teff production, and their labor burden exceeds that of their husbands since they perform reproductive activities in which men do not participate. Most women are involved in the production, processing and retailing of teff. In turn, their husbands control the wholesale process and cash generated. However, it is difficult to calculate the labor share of women in the household. There are very weak linkages between actors of the entire teff value chain. Among the main determinants of teff market supply, education of the respondent, land area, market information and cooperative membership have a positive effect. Conversely, distance to market negatively affected teff market supply. Therefore, enhancing cooperation between teff value chain actors and providing women with access to training, education and extension services should be a policy priority in the study areas.
\end{abstract}

Keywords: actor, gender, multiple regression, teff, value chain

\section{INTRODUCTION}

\section{Background of the study}

Women contribute substantially to agricultural economies in developing countries, and their roles vary con- siderably between and within regions (Raney et al., 2011). In Africa, women share half of agricultural labor force (Lal and Khurana, 2011). The African continent has been facing a range of economic and socio-political challenges which have disproportionately impacted women (Uzodike and Onapajo, 2013).

In Central and South-Eastern Europe, women are much more concentrated in the service sector (Lal and Khurana, 2011). However, they usually have lowerpaying jobs (Raney, et al., 2011). In Ethiopia, women contribute $45 \%-75 \%$ to crop production (BMFG, 2010) but face barriers in getting access to inputs and agricultural extension services (ACDI/VOCA, 2013). In subSaharan Africa, women own about $15 \%$ of all land (Lal and Khurana, 2011); in Ethiopia, only $18.6 \%$ of women are land owners (MoWA, 2005). Without land, women's access to formal credit and participation in value chains is impossible (Fletschner and Kenney, 2014). Moreover, Ethiopian women are highly concentrated in low-paying jobs (Belachew et al., 2011). Gender-based violence is widely prevalent in Africa, and the gender pay gap in sub-Saharan countries is 32\% (Leopold et al., 2016). Ethiopia ranked 109 out of 144 countries by gender pay gap in 2016 (Leopold et al., 2016).

In Europe, the disparity in gender roles is narrow and gender-based violence is rare. Both men and women perform domestic and productive activities (Van De Vijver, 2007), and thus the gender gap in western Europe is closing fast. Although women are equally educated

\footnotetext{
$\bowtie$ Adugna Eneyew, Jimma University College of Agriculture \& Veterinary Medicine, Department of Rural Development \& Agricultural Extension, 0000 Jimma, Ethiopia, e-mail: adugna_e@yahoo.com; https://orcid.org/0000-0003-0480-4535
} 
Tekalign, S., Eneyew, A., Mitiku, F. (2020). Gender roles in teff value chain in Borecha District of South Western Ethiopia: husband and wife comparisons. J. Agribus. Rural Dev., 1(55), 93-105. http://dx.doi.org/10.17306/J.JARD.2020.01212

as men (Leopold et al., 2016), they earn less than men in many European countries (AAUW, 2015).

There are two dominant approaches to gender planning. The Women in Development (WID), Women and Development (WAD) created in the 1970s and the Gender and Development (GAD) approach created in the 1980s. WID emphasizes the need for integrating women into the developmental process and improving their welfare. In turn, WAD focuses on the relationship between women and development processes rather than on the integration of women into development. Conversely, GAD emphasizes the social construction of gender and the need for women empowerment (Rathgeber, 1990; Uzodike and Onapajo, 2013).

All of the above approaches were introduced in Africa (Uzodike and Onapajo, 2013). Much of the concern of ensuring gender equality in developing countries like Ethiopia is improving women's economic status by providing women and men with equal rights to access, own and control land and other assets, which is very similar to WID/WAD. For instance, the African Union gender policy emphasizes gender mainstreaming and installing institutional and policy frameworks that promote gender equality (AU, 2009). However, the approach prevailing in developed regions like Europe focuses on narrowing the gender gaps by reducing disparities in women's labor market participation, pay, and decision making (EC, 2018). Without taking side of any gender approaches, this study aims at identifying family-level gender roles in Ethiopian agriculture.

\section{Problem statement}

Analyzing gender roles in agriculture in developing countries in general, and in teff ${ }^{1}$ value chain in Ethiopia in particular, is very important for many reasons. First, agriculture is the foundation of the Ethiopian economy, employing more than $80 \%$ of the rural community (of which $50 \%$ are women) of the country's over 100 million people, and contributing 49.1\% to GDP (Adenew, 2004). The vast majority of Ethiopians live in rural areas

${ }^{1}$ Teff (Eragrostis tef, Zucc.), an ancient cereal grain widely grown and consumed in Ethiopia and Eritrea. Teff is mainly processed into different foods and beverages, such as breads, sweet unleavened bread, porridge, pancakes, biscuits, cookies, cakes, stir-fry dishes, casseroles, soups, stews and puddings (Arendt and Zannini, 2013). It has been growing in popularity across the world in recent years. and engage in rain-fed subsistence agriculture. However, Ethiopia has not yet realized its potential (Belete et al., 1991). Rural women play a great role in Ethiopian agriculture by supplying labor. Despite the importance of agriculture in the Ethiopian economy, and the contribution of women to the agricultural sector, studies on gender aspects of agricultural commercialization are relatively scarce (Aregu et al., 2011). Societies with a long history of agriculture have less equality in gender roles because of more patriarchal values and beliefs regarding the proper role of women in society (Hansen et al., 2015). Second, efforts have been made at global and local levels to achieve gender equality. For instance, sustainable development goal No. 5 was to achieve gender equality and empower all women and girls, with a first target of ending all discrimination against women and girls everywhere (Leach, 2015). Moreover, paying attention to gender is not a matter of ideology but rather a matter of development effectiveness (Meinzen-Dick et al., 2012). Therefore, incorporating gender issues more widely and systematically in agricultural research is of paramount importance. In Ethiopia, too, there were policy initiatives working towards strengthening the position of women in the agricultural sector. The gender target aspires to safeguard rights such as access to land, credit, and other productive resources, and to protect women from other deprivations, such as longer working days, violence and discrimination (Aregu et al., 2011).

Third, in Ethiopia, women's contribution to the production and harvesting of major food crops in general, and teff in particular, is tremendous. More than $80 \%$ of the 12.6 million hectares of land cultivated by smallholder farmers is under cereals. Female farmers contribute more significantly to crop production than their male counterparts (Ogato et al., 2009). Teff covers $23.85 \%$ of cultivated land and is ranked first, followed by maize and wheat which cover $16.79 \%$ and $14.96 \%$, respectively (CSA, 2018; Tura et al., 2016). Teff is the most favorable indigenous staple crop in Ethiopia (Diao et al., 2010), and local people have a strong cultural attachment to it. Also, teff generates an annual income of ca. 464 million USD for local farmers (Minten et al., 2013). With a trend of growing teff consumption at international level, the importance of teff as a cash crop is expected to increase the benefits for farmers and other actors in the teff value chain (Amentae et al., 2016). Fourth, according to Hauenstein (2015), the teff value chain was found to be quite heterogeneous, differing 
considerably between the components of the value chain. With demand for teff growing stronger than productivity, teff prices have been increasing progressively, and teff has become unaffordable for many Ethiopians. Hence, an analysis of the teff value chain can help understand gender roles and relationships which influence the division of work, the use of resources, and the sharing of benefits from the chain between women and men.

Gender relations affect, and are affected by, the ways in which value chains function. Gender is thus an important aspect of value chain analysis (Mutua et al., 2014). Value chains offer great opportunities to men and women through better market linkages and employment opportunities. At the same time, the way these value chains operate can affect some groups negatively, including through low wages (Gammage et al., 2009; Jauch, 2002). Barriers like access to capital and technologies influence people's, and especially women's, participation to and benefits from value chains (Kaplinsky and Morris, 2000). Often, women have lower access to capital and technologies than men, which decreases their participation in value chain stages with the highest economic returns, and confines them to lower-profit nodes (Coles and Mitchell, 2011).

Finally, understanding the gender relationship in the teff value chain needs a local, context-specific, concise and systematic analysis. Among potential teff producing woredas (districts) in southwestern Ethiopia, Borecha was selected as a targeted for this study. In the woreda covered by this study, nothing is known and studied about gender roles in relation with the teff value chain. Therefore, this paper contributes to the knowledge gap by identifying gender roles in relation to teff value chains.

\section{METHODOLOGY}

The study was conducted in Borecha woreda located in south-western Ethiopia. A two-stage sampling technique was employed to select the respondents. In the first stage, three teff-producing kebeles (smallest administrative units) were randomly selected. In the second stage, the list of households in the kebeles sampled was used to select 117 sample farmers at a $95 \%$ confidence interval with the Cochran (1977) sampling formula. Similarly, 11, 15, 14, 7 and 5 collectors, retailers, consumers, processors, and wholesalers were respectively selected.
Data was collected from primary and secondary sources. Primary data was collected from sample teff producers using a pre-tested structured interview schedule handled by trained enumerators. Secondary data was collected from various sources, including public organizations, documented materials from the woreda ${ }^{2}$ agricultural office, and woreda-level trade and industry offices. Moreover, to triangulate and get in-depth understanding of the teff value chain at community level, Focus Group Discussions (FGD) and key informant interviews were used in each kebele ${ }^{3}$ sampled. Thus, in each kebele sampled, one FGD was conducted with a total of 30 female and 28 male participants. The key informant interview was carried out both at woreda and kebele level with the Woreda Agriculture Office, Trade and Industry Office, and kebele administration and extension services. A total of 10 key informant interviews were conducted.

Descriptive statistics and econometrics were used for data analysis. The Statistical Package for Social Sciences (SPSS) version 20 was used. Statistical tools of data analysis, such as percentages, means, standard deviations, $t$-test, $\chi^{2}$-test and maps, were used in describing marketing functions and household characteristics by gender.

A cost-benefit analysis was conducted using the standard formulas.

(i) The gross marketing margin (GMM) is the difference between retail price $\left(\mathrm{R}_{\mathrm{P}}\right)$ and farmgate price $\left(\mathrm{F}_{\mathrm{P}}\right)$.

$$
G M M=\left[(R)_{p}-F_{p}\right] \cdot 100
$$

(ii) The total gross marketing margin (TGMM) is the ratio of the difference between consumer $\left(\mathrm{C}_{\mathrm{P}}\right)$ and farmer price $\left(\mathrm{F}_{\mathrm{P}}\right)$ to consumer price.

$$
\mathrm{TGMM}=\frac{C_{p}-F_{p}}{C_{p}} \cdot 100
$$

(iii) The Net Marketing Margin (NMM) of producers, traders and processors was calculated as a percentage of the final price earned by the intermediaries as their net income after their marketing costs are deducted.

$$
\mathrm{NMM}=\frac{\mathrm{GMM}-\mathrm{C}}{R_{p}} \cdot 100
$$

\footnotetext{
${ }^{2}$ Woreda is a third-level administrative unit in Ethiopian context (region-zone-woreda-kebele).

${ }^{3}$ Kebele is a fourth-level administrative unit in Ethiopian context (region-zone-woreda-kebele)
} 
where: GMM is the gross marketing margin; $\mathrm{C}$ is the cost; and $R_{P}$ is the retail price

(iv) The farmers' share $(F S)$ is the percentage ratio of farm price $\left(F_{P}\right)$ to retail price $\left(R_{P}\right)$ :

$$
F S=\frac{F_{p}}{R_{p}}
$$

Multiple linear regression models were used to assess the factors affecting teff supply to the market. The multiple regression equation is specified as follows $(\mathrm{Gu}-$ jarati, 2009):

$$
Y_{i}=\beta_{0}+\beta_{1} X_{1}+\ldots \beta_{n} X_{n}+\varepsilon_{i}
$$

where:

$Y=$ quantity of teff supplied to the market;

$X=$ vectors of explanatory variables;

$\beta_{1}-\beta_{n}=$ vector of parameters to be estimated;

$\varepsilon=$ error term.

The dependent variable of the multiple regression model is Quantity of teff supplied to market (QT_SUPP). It is the amount of teff supplied to the market by the household.

\section{Independent variables}

The independent variables were identified based on empirical evidence and generally accepted theory. Accordingly, this study identified socio-demographic, socioeconomic and institutional variables that influence the quantity of teff supplied to the market.

Socio-demographic variables include age, gender and education of household head and family size. Age of the household head (in years) could positively influence the quantity of supply because the older a person is, the more experience he/she has in farming and weather forecasting. A study conducted by Abebaw (2003) indicated that age has a significant effect on household crop production. Education of the household head (in years of schooling) is hypothesized to positively affect market supply. This is since a farmer with extensive knowledge can adopt better practices than illiterates, and thus increase market supply (Fakoya et al., 2007). For instance, education has improved the supply of fruits to market by farmers in northern Ethiopia (Ayalew, 2015). Family size is hypothesized to influence quantity supplied negatively. This is because the more members the household hosts, the greater is the demand for food consumption which reduces the amount of marketable production.
Socioeconomic variables include the size of cultivated land, number of animals owned and income from non-farm activities. The size of cultivated land (in hectares) is hypothesized to positively affect the quantity of teff supplied to the market. Farmers who have a larger area of cultivated land are more likely to produce more teff than those who have a smaller area of land. A study on fruit supply in northern Ethiopia reports that land size can improve the marketable surplus of fruits (Ayalew, 2015). The number of animals owned (in tropical livestock units, TLU) is hypothesized to negatively influence the quantity of teff supplied to market. This is because farmers who own more livestock reallocate land and labor from crops to livestock (Rehima, 2006). Income from non-farming activities is a dummy variable measured in terms of whether the household did (1) or did not (0) earn an income from non-farming activities. Participation in non-farm income-generating activities shifts labor and was therefore expected to negatively influence the market supply of teff.

The institutional variables included are distance from market, access to market information, access to extension services, access to credit and membership in cooperatives. Distance to Nearest Market (in hours of walking time) is hypothesized to negatively affect marketable supply of teff. The closer the market, the smaller the transportation charges; the shorter the walking time; the smaller the other marketing costs; and the better the access to market information and facilities. A fruit production case study shows that the distance to market adversely affects the volume of total sales (Ayalew, 2015; Tadesse, 2011). Access to Market Information is a dummy variable taking a value of 1 if the farmer has access to market information and 0 otherwise. It was hypothesized to positively influence the marketable supply of teff because producers that have access to market information are likely to supply more teff to the market. Market information significantly raises the market sales of fruits (Ayalew, 2015). Credit Access is a dummy variable taking the value of 1 if the household took a loan, and 0 otherwise. Access to credit will enhance the farmer's financial capacity to purchase inputs, thereby increasing teff production and market share. Evidence has shown that access to loans significantly determines the farmers' market participation (Urquieta and Rosa, 2009). Extension service is a dummy variable taking a value of 1 if the household 
Tekalign, S., Eneyew, A., Mitiku, F. (2020). Gender roles in teff value chain in Borecha District of South Western Ethiopia: husband and wife comparisons. J. Agribus. Rural Dev., 1(55), 93-105. http://dx.doi.org/10.17306/J.JARD.2020.01212

has contacted a development agent, and 0 otherwise. Extension is expected to have a positive effect on market supply of teff through its stimulation of production and productivity. Farmers that have frequent contact with extension workers are more likely to adopt technology. Membership to a Cooperative is a dummy variable which takes a value of 1 if the household is a member of a cooperative engaged in any business, and 0 otherwise. Cooperatives improve their members' understanding of the market and strengthen the relationships between them. Therefore, being a cooperative member is expected to positively affect the marketed supply of teff.

\section{RESULTS AND DISCUSSION}

\section{Demographic, socioeconomic and institutional characteristics of respondents}

Table 1 presents the demographic and socioeconomic characteristics of the respondents sampled. The findings revealed that $6.8 \%$ of males and $20.5 \%$ of females are illiterates. In the sample, $78.6 \%$ and $76.9 \%$, of males and females (respectively) had a primary education, while $14.6 \%$ and $2.6 \%$ of males and females (respectively) had a secondary education. The comparison of education levels between males and females revealed

Table 1. Demographic and socioeconomic characteristics of respondents

\begin{tabular}{|c|c|c|c|c|c|c|c|}
\hline \multirow{2}{*}{$\begin{array}{l}\text { Demographic } \\
\text { variable }\end{array}$} & \multicolumn{2}{|c|}{ Item } & \multirow{2}{*}{\multicolumn{2}{|c|}{$\begin{array}{c}\text { Male } \\
(\%)\end{array}$}} & \multirow{2}{*}{\multicolumn{2}{|c|}{ Female }} & \multirow{2}{*}{$C h i^{2}$} \\
\hline & & & & & & & \\
\hline \multirow{2}{*}{$\begin{array}{l}\text { Access to market } \\
\text { information }\end{array}$} & \multicolumn{2}{|c|}{ Yes } & \multicolumn{2}{|c|}{74.4} & \multicolumn{2}{|c|}{47.9} & $7.2^{*}$ \\
\hline & \multicolumn{2}{|c|}{ No } & \multicolumn{2}{|c|}{25.6} & \multicolumn{2}{|c|}{52.1} & \\
\hline \multirow{2}{*}{$\begin{array}{l}\text { Participation in non- } \\
\text { farm activities }\end{array}$} & \multicolumn{2}{|c|}{ Yes } & \multicolumn{2}{|c|}{40.2} & \multicolumn{2}{|c|}{43.5} & 0.62 \\
\hline & \multicolumn{2}{|c|}{ No } & \multicolumn{2}{|c|}{59.8} & \multicolumn{2}{|c|}{56.5} & \\
\hline \multirow{2}{*}{$\begin{array}{l}\text { Cooperative } \\
\text { member }\end{array}$} & \multicolumn{2}{|c|}{ Yes } & \multicolumn{2}{|c|}{58.1} & \multicolumn{2}{|c|}{0} & 0.43 \\
\hline & \multicolumn{2}{|c|}{ No } & \multicolumn{2}{|c|}{41.9} & \multicolumn{2}{|c|}{100} & \\
\hline \multirow[t]{2}{*}{ Access to credit } & \multicolumn{2}{|c|}{ Yes } & \multicolumn{2}{|c|}{48.9} & \multicolumn{2}{|c|}{63.2} & 0.1 \\
\hline & \multicolumn{2}{|c|}{ No } & \multicolumn{2}{|c|}{51.1} & \multicolumn{2}{|c|}{36.8} & \\
\hline \multirow[t]{2}{*}{ Access to extension } & & & & & & & 0.48 \\
\hline & & & & & & & \\
\hline Socioeconomic & & & & & & & t-test \\
\hline variables & Mean & SD & Mean & SD & Mean & $\mathrm{SD}$ & \\
\hline Age & 47.9 & 11.7 & 40.3 & 8.1 & 44.1 & 10.7 & $5.7 *$ \\
\hline Family size & & & & & 6 & 0.1 & \\
\hline TLU & & & & & 10.1 & 0.3 & \\
\hline Land under teff & & & & & 0.87 & 0.3 & \\
\hline Educational & & & & & & & $25.2 *$ \\
\hline Illiterates & 6.8 & 0.36 & 20.5 & 0.7 & 13.6 & 0.53 & \\
\hline Grade $1-8$ & 78.6 & 2.7 & 76.9 & 2.6 & 77.5 & 2.65 & \\
\hline Grade 9-12 & 14.6 & 0.5 & 2.6 & 0.13 & 8.6 & 0.35 & \\
\hline
\end{tabular}

Note: * mean statistical significance $1 \%$ probability levels. 


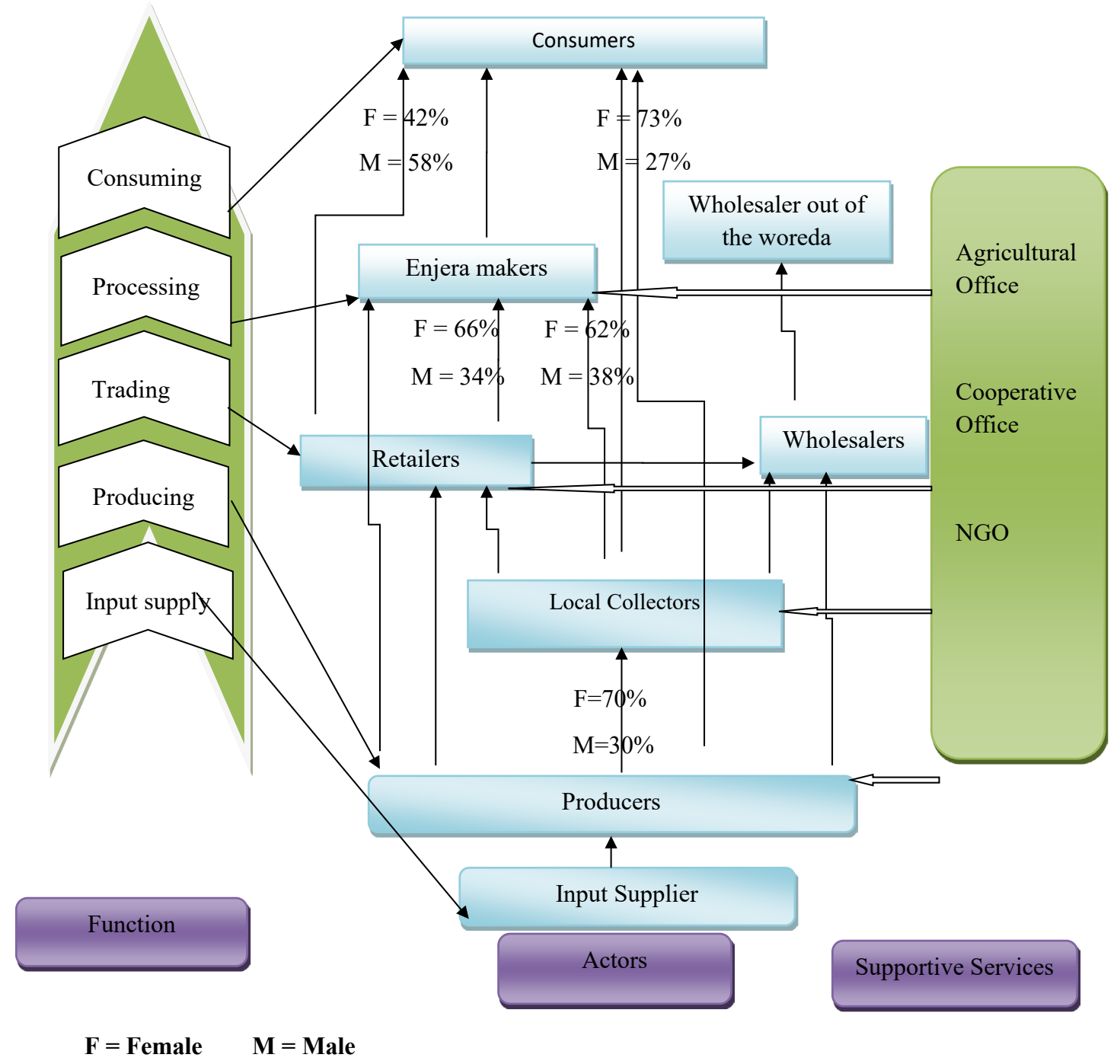

Fig. 1. Gendered map of the teff value chain in Borecha district Source: elaboration based on survey results, 2016.

a statistically significant difference based on a chi-square test. It was found that a greater proportion of females had lower levels of education compared to that of their male spouses. In general, rural Ethiopian people have a low educational status, and the situation of rural women is even worse. Access to formal credit showed that only ca. $48.9 \%$ of husbands received credit from micro-financing institutions and other sources whereas $63.2 \%$ of wives received credit. About $58.1 \%$ of men were cooperative members whereas none of the women was a member. Also, approximately $58.1 \%$ of males and $18.8 \%$ of women had access to extension services. This indicates that men are better positioned to gain useful information that may empower them in the teff value chain, although the statistics do not reveal a significant difference. Over $40 \%$ of men and women participated in non-farm activities. About $74.4 \%$ of male respondents reported that they receive market information, while the corresponding ratio for women was only $47.9 \%$. Access to market information varies significantly between men and women. The average age of males and females was 47.9 and 40.3 years, respectively. Age is one of the 
household characteristics important in describing the household's situation, and can provide a clue on working ages of households. Age is assumed to have a relationship with the farmer's outlays, gender roles and decisions on the teff value chain. Most respondents were found to be middle-aged. The result of the t-test shows that the average husbands' age is significantly higher than the wives' age. The minimum and maximum family size of households was 2 and 12, respectively. The average family size of the sample households is six persons while the total number of animals (in tropical livestock units, TLU) and teff farm land are 10.1 and 0.87 ha, respectively. The minimum and maximum farm area under teff was 0.125 ha and 3 ha, respectively (Table 1 ).

\section{Gender roles in the teff value chain}

The teff value chain involves the following value-adding activities: production, processing, marketing and consumption by respective different actors. Currently, these activities are not coordinated to improve competitiveness and efficiency. The existing scenario shows that teff value chain actors are not provided with an opportunity to talk to each other about issues affecting the entire value chain. Both men and women participate in input supply, production as well as flow of the product to consumer. Figure 1 shows different levels of the teff value chain in the study area. It includes different levels, actors and functions involved in the flow of the product, and the flow of product quantities (by gender) through different levels. The result indicates that the share of women in processing teff into enjera is higher than men ( $66 \%$ vs. $34 \%$ for men). Similarly, their proportion in retaining marker is substantially high.

According to the teff value chain map (Fig. 1), input suppliers deliver inputs such as improved seed, herbicides, pesticides and fertilizers. The Woreda Office of Agriculture (WOA) and cooperatives are the main actors responsible for the supply of inputs. Development agents play a facilitation role in collecting farmers' input demand and in input distribution. Input supply in the villages surveyed is dominated by men who can easily travel long distances to purchase inputs from wholesalers located in urban areas. Women's role in input supply, procurement and distribution is very limited. This is because husbands restrict the movement of their wives, thus reducing their role in input supply activities.

Teff producers are smallholder farmers who produce and sell teff in local markets. About $29 \%$ of households sampled have sold to retailers; $23 \%$ to collectors; $7.7 \%$ to wholesalers; $13.7 \%$ to enjera makers; and $26.5 \%$ to consumers. To transport teff to the market, $41.9 \%, 23.9 \%$ and $34.2 \%$ of the households rely on animal carts, vehicles and head/backload, respectively. About $25 \%$ of men and $75 \%$ of women transport teff grain to the market. Both female and male producers participated in valueaddition activities from land preparation through to sowing, fertilizer application, field management, harvesting, cleaning and marketing.

Teff collectors are (licensed or unlicensed) individuals who collect teff from farmers, especially at harvesting time. Out of the 12 teff collectors, 10 are men whereas only 2 are women. They also rely on human labor, donkeys and vehicles to transport produce to wholesalers, retailers, consumers and enjera makers. Their main functions in the teff value chain are sorting, grading and transporting.

Teff wholesalers are involved in buying teff from collectors, retailers and producers in larger volumes in Agaro and Mettu market centers. There are only four teff wholesalers in the study area and all are men.

Teff retailers are traders who purchase teff from producers and collectors and sell it in small quantities to consumers. They are very numerous as compared to others. They are specialized to sell teff only as grain. Among the five female retailers, three sell directly to consumers, one sells to wholesalers, and the other one to enjera makers. Among the ten male retailers, three sell directly to consumers, five sell to wholesalers, and two sell to enjera makers. Retailers add value by cleaning, grading and transporting the product.

Enjera makers and sellers buy teff grain from different actors such as retailers, wholesalers, collectors and sometimes from producers. They process enjera and supply it to consumers. This activity was performed solely by women.

Consumers are the end users of teff. A total of 14 consumers were interviewed (11 men and 3 women). They purchase teff grain from producers, collectors, retailers, wholesalers and enjera makers. Households buy it for their own consumption, while hotels and restaurants add value and make profit out of it.

As regards cooperatives, there is one cooperative union in the area (called Buno Bedele) to which primary cooperative societies are affiliated. In the woreda, a farmers' cooperative was established in Yanfa town in 2003 with 250 members, and started buying coffee, 
Tekalign, S., Eneyew, A., Mitiku, F. (2020). Gender roles in teff value chain in Borecha District of South Western Ethiopia: husband and wife comparisons. J. Agribus. Rural Dev., 1(55), 93-105. http://dx.doi.org/10.17306/J.JARD.2020.01212

teff, maize, sesame and peanuts from the members in 2015. They purchased commodities from 12 farmers' cooperative societies in rural areas with a total of 1929 members. Also, they supply fertilizers to cooperative members and non-members in the woreda. The union not only participated in the teff value chain by buying teff, but also reduced price volatility and financial liquidity problems faced by farmers.

Supportive actors (value chain supporters) provide auxiliary services and represent the common interests of value chain operators. The main teff value chain supporters in the study area are the Agriculture Office, Cooperative Agency and Trade and Marketing Development offices. The Agriculture Office plays a critical role in creating awareness and building capacity of teff farmers (through such measures as training, input supply, credit facility etc.). The Office of Trade and Market Development facilitates market linkages and business networking. However, participants of the FGDs confirmed that the office is not efficient in timely providing market and contracting information and price forecasts.

\section{Value addition and benefit sharing along the teff value chain}

The cost-benefit analysis of the value chain process is important in identifying value chain actors who derive greater benefits and in tracing the position of farmers in this regard. The key points to be considered in a value chain analysis are the marketing costs (incurred at different levels by market actors along the channels) as well as the producers' and intermediaries' margin on and share in prices paid by consumers or end buyers.

Although the production cost is incurred by teff farmers, it is mostly incurred during the production phase rather than when marketing their produce. They expend ETB 241.81 per quintal. Teff is produced using family labor and hired labor, and hence production costs are low. As displayed in Table 2, of all the teff value chain actors, enjera makers have the largest share in gross marketing margin (32\%), followed by producers $(29 \%)$, wholesalers (19.6\%) and retailers (14\%), while collectors earn the smallest value $(5.4 \%)$. When it comes to the distribution of profits between actors in the teff value chain, enjera makers and producers receive the greatest share of $34.9 . \%$ and $26.5 \%$, respectively, followed by wholesalers $(20.2 \%)$, retailers $(14.4 \%)$ and collectors $(4.1 \%)$.

\section{Gender roles in the teff value chain}

Figure 2 presents the result of a Likert scale used to assess the distribution of labor between male and female spouses. The results indicate that men largely dominate in land preparation and marketing activities whereas women are concentrated at weeding and harvesting activities. But when it comes to community roles, the figures observed were similar.

\section{Access to and control over resources}

Women's access to resources and services in developing countries is constrained by cultural, traditional and

Table 1. Marketing costs of actors in the teff value chain

\begin{tabular}{lcccccc}
\hline \multicolumn{1}{c}{ Item (ETB/quintal) } & Producers & Collectors & Wholesalers & Retailers & Enjera makers & Horizontal total \\
\hline Purchase prices & 0 & 1237.5 & 1400 & 1331.25 & 1325 & 5293.75 \\
Production cost & 241.81 & 0 & 0 & 0 & 0 & 241.81 \\
Marketing cost & 107.5 & 68.5 & 81.5 & 61 & 84 & 402.5 \\
Total cost & 349.31 & 1306 & 1481.5 & 1392.25 & 1409 & 644.31 \\
Sale price & 1266.4 & 1431.25 & 2100 & 1831.25 & 2475 & 9103.9 \\
Gross margin & 1024.59 & 193.75 & 700 & 500 & 1150 & 3568.34 \\
\% share in gross margin & $29 \%$ & $5.4 \%$ & $19.6 \%$ & $14 \%$ & $32.2 \%$ & $100.00 \%$ \\
Net benefit (profit) & 809.59 & 125.25 & 618.5 & 439 & 1066 & 3058.34 \\
$\%$ share in profit & $26.5 \%$ & $4.1 \%$ & $20.2 \%$ & $14.4 \%$ & $34.9 \%$ & $100.00 \%$ \\
\hline
\end{tabular}

Source: elaboration based on survey results, 2016. 


\section{Gender-based labor division in teff production and marketing}

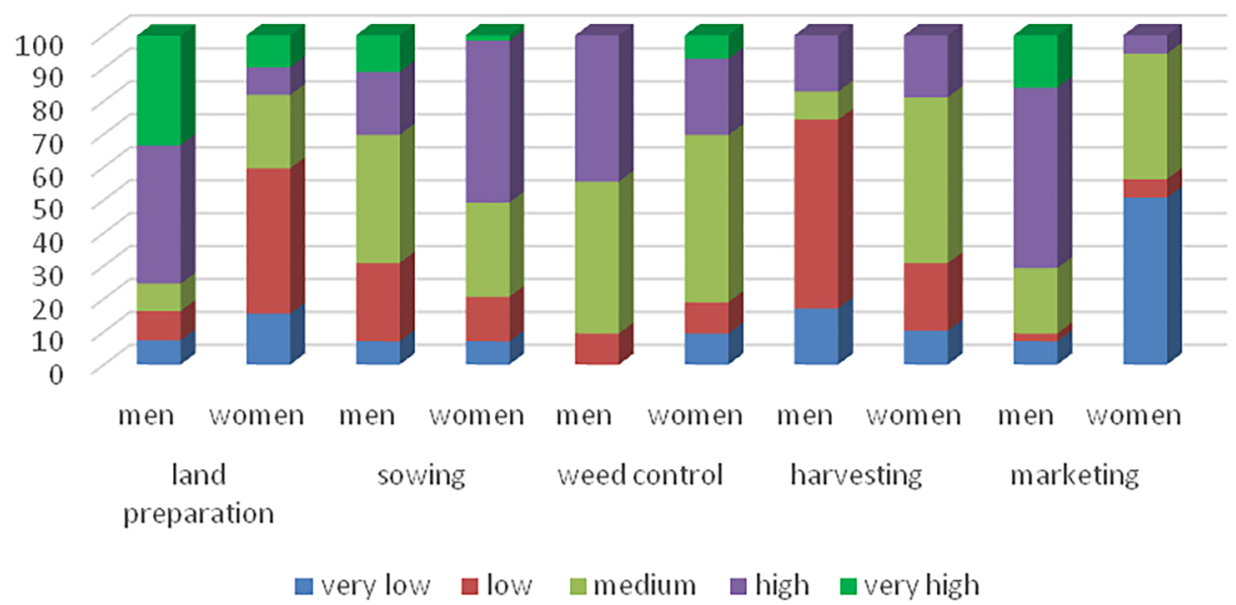

Fig. 2. Male and female roles in the teff value chain Source: survey result, 2016.

Table 2. Respondents' access to services and resources (\%)

\begin{tabular}{llcccccc}
\hline & Gender & Land resource & Cash & Education & Credit & Training & Extension \\
\hline \multirow{2}{*}{ Access } & Men & 91.5 & 89.6 & 86.3 & 48.9 & 75 & 58.1 \\
& Women & 85.5 & 46.4 & 43.1 & 63.2 & 25 & 18.2 \\
\hline
\end{tabular}

Source: survey result, 2016.

socioeconomic factors. Therefore, exact information about men's and women's access to and control over key productive inputs in their married life is critical in order to design agricultural development interventions. In view of the above, the respondents were asked about their access to the following resources and services.

Table 3 shows that nominal access to land (especially farmland) is not a big problem because of the reforms implemented in rural Ethiopia. About 91.5\% of men and $85.5 \%$ of women have access to land which is owned by the household. However, the result about $76.1 \%$ (Fig. 3) indicates that men exert strong control over land, implying that they have a greater controlling power over land than women. On the other hand, both men and women reported that they have equal access to farming and home equipment, although women have a slightly stronger control over its use. Regarding access to cash, over $89.6 \%$ and $46.4 \%$ of men and women, respectively, reported that they have access to cash from different sources. In turn, when it comes to controlling the use of cash in the family, the majority $(76.1 \%)$ indicated that men's role is very strong in controlling cash, while only $20.5 \%$ of women do have the same status. Data exhibits that about $63.2 \%$ women accessed credit, and that there is only a minor difference in control over credit between men and women.

Generally, the proportion of men who have access to training and education is higher than that of women. Similarly, the decision as to whether attend training and education is mainly made by men (the score varies from strongly high to high for men). When it comes to accessing extension services, about $97.4 \%$ of men accessed it while the figure for women is $67.2 \%$. This would have an implication on the adoption of new technology as the extension system is mainly targeted at men. This may lead to the fact that women have less access to 

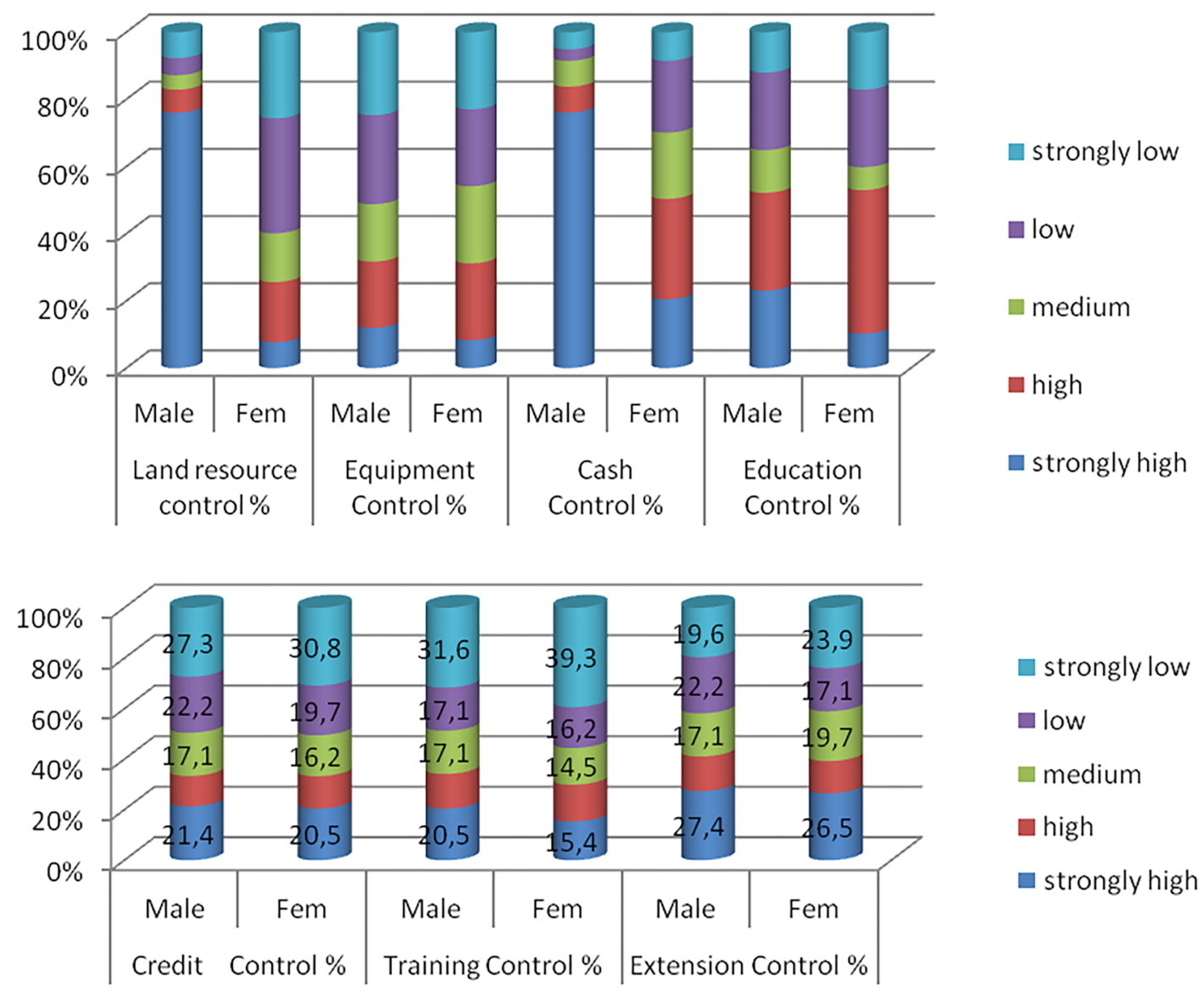

Fig. 3. Control over services and resources

Source: elaboration based on survey results, 2016.

technology, implying lower farm productivity and low levels of farm income.

\section{Factors affecting quantity of teff supplied to the market}

This section presents the result of the Multiple Linear Regression (MLR) model. Prior to the estimation, data was tested for the presence of multicollinearity and heteroscedasticity. This study used the Variance Inflation Factor (VIF) to detect the problem of multicollinearity (Gujarati, 2009). The value of VIF was below 0.75, indicating that data is not affected by mutlicollearity. The Koenker-Bassett (KB) test of heteroscedasticity (Gujarati, 2009) was carried out and revealed the presence of heteroscedasticity in the dataset. A robust standard error method was employed to overcome that problem.
The result of the MLR is presented on Table 4. The overall goodness of model fit is high $\left(\mathrm{R}^{2}=84.39 \%\right.$, adj $\mathrm{R}^{2}=83.65 \%$ ), indicating that over $85 \%$ of variation in teff quantity supplied is due to the hypothesized variables. The model suggests that the quantity of teff supplied to the market is significantly influenced by education, distance to nearest market, land area, cooperatives and market information.

The result shows that education of the household head (EDULEVL) positively and significantly influences the quantity of teff supplied to the market. The finding implies that improving the education level of the household head by one schooling year, ceteris paribus, increases the quantity of teff supplied to the market by 0.08 q. Education broadens the farmers' intelligence and enables them to perform the farming activities in 
Tekalign, S., Eneyew, A., Mitiku, F. (2020). Gender roles in teff value chain in Borecha District of South Western Ethiopia: husband and wife comparisons. J. Agribus. Rural Dev., 1(55), 93-105. http://dx.doi.org/10.17306/J.JARD.2020.01212

Table 3. Results of the Robust MLR model

\begin{tabular}{llccccc}
\hline QUNSOKUN & Coeff. & Std. err. & $\mathrm{T}$ & \multicolumn{2}{c}{$\mathrm{P}>|\mathrm{t}|$} & \multicolumn{2}{c}{$[95 \%$ conf. interval $]$} \\
\hline AGHH & -0.0189 & 0.0065 & -1.2 & 0.186 & -0.0225 & 0.0034 \\
EDULEVL & $0.08254^{* *}$ & 0.1363 & 2.54 & 0.034 & 0.0235 & 0.1433 \\
DISMKT & $-1.6176^{* * *}$ & 0.3481 & -10.8 & 0.000 & -1.9104 & -1.326 \\
NONFARM & -0.1565 & 0.0376 & -0.23 & 0.665 & -0.3305 & 0.2112 \\
LAND & $2.9832^{* * *}$ & 0.3376 & 8.71 & 0.000 & 2.3254 & 3.6529 \\
TLU & 0.21575 & 0.0208 & 0.94 & 0.369 & -0.0523 & 0.0658 \\
COOPRT & $0.462317^{* *}$ & 0.1979 & 2.23 & 0.041 & .856267 & 0.7731 \\
CRDT & -1.2487 & 0.1526 & -1.33 & 0.104 & -0.5502 & 0.0513 \\
EXTCON & 0.2525 & 0.1650 & 0.31 & 0.759 & -0.4525 & 0.3540 \\
MRKTINF & $0.3567 *$ & 0.1934 & 1.61 & 0.064 & .74658 & 0.0312 \\
Cons & 2.1256 & 0.8170 & 2.77 & 0.014 & 0.41122 & 3.5397 \\
\hline
\end{tabular}

R-squared $=84.39 \%$, Adj R-squared $=83.65$

$* * *, * *$ and $*$ represent significance at $1 \%, 5 \%$ and $10 \%$ probability levels, respectively.

Source: own compilation, 2016.

a smarter, more accurate and efficient way (Fakoya et al., 2007). Astewel (2010) found that if paddy rice producers get educated, the amount of paddy rice supplied to the market increases.

The Distance to Nearest Market (DISMKT) negatively and significantly influences the quantity of teff supplied to the market. The result shows that as the distance from the nearest market increases by one-hour walk, the quantity of teff supplied to the market decreases by $1.6 \mathrm{q}$. This may be due to the reason that as the distance to the market center increases, so do transportation and transaction costs. This is in line with Ayelech (2011) who indicated that distance to market resulted in a decline in the marketed surplus of avocado.

The Size of Cultivated Land (LAND) has a positive and significant influence on the quantity of teff supplied to market. The larger the area of land allocated by the households to teff production, the greater the marketed surplus. A one-hectare increase in the area of land allocated to teff production increases the marketed quantity of teff by 2.99 quintal. This result is in line with Haymanot (2014) who found a similar result for wheat.

Membership to Cooperative (COOPRT) has a significant positive impact on teff supply to the market.
If a farmer joins a cooperative, its teff supply to market increases by 0.46 quintal, ceteris paribus.

Access to Market Information (MRKTINFO) has a positive and significant influence (at a $10 \%$ level) on the quantity of teff supplied to the market. Farmers who have access to market information supply 0.35 quintal more teff to the market, on average, than those who have no market information. This is in line with Mohammed (2011) who illustrated that farmers' access to market information significantly increases the marketable supply of teff.

\section{CONCLUSION AND POLICY IMPLICATION}

Using unique cross-sectional data from husbands and wives living in south-western Ethiopia, this paper analyzed gender roles in the teff value chain. The descriptive result reveals differences in the family with respect to teff value chain gender roles. Women worked longer than men in terms of hours per day in all activities. While both men and women have similar access of resources, men have a greater controlling power over them.

The teff value chain suffers from inefficiency in timely providing market and contracting information and 
Tekalign, S., Eneyew, A., Mitiku, F. (2020). Gender roles in teff value chain in Borecha District of South Western Ethiopia: husband and wife comparisons. J. Agribus. Rural Dev., 1(55), 93-105. http://dx.doi.org/10.17306/J.JARD.2020.01212

price forecasts. Cooperation between actors along the teff value chain in the study area is poor. This results in price information asymmetry and weakens the bargaining power of farmers and traders. The result shows that land area, cooperative membership and education have a positive impact on the quantity of teff supplied to market, whereas the influence of market distance is negative.

Different policy implications can be drawn based on the findings of this study. First, it is important to encourage continuous education and training that would improve the farmers' production knowledge, skills and attitudes. Second, the introduction of improved varieties, application of chemical fertilizers and use of modern technologies should be promoted to increase production. This could be achieved by strengthening the extension and cooperatives systems. Third, teff market supply was significantly and negatively affected by the distance to nearest market. Therefore, access to market should be enhanced to help farmers supply their produce. Fourth, the survey result shows that cooperatives have a positive impact on teff supply to the market. Cooperatives improve their members' understanding of the market and strengthen the relationships between them. Therefore, enhancing the capacity of cooperatives through trainings needs to be emphasized. Finally, the result of this study showed that access to market information positively affected the quantity of teff supplied. Farmers in the study area do not get timely market information on which they rely in making their marketing decisions. They depend on traders and other farmer friends for price information. Therefore, there has to be an institution that can convey reliable and timely market information required by all stakeholders simultaneously.

\section{ACKNOWLEDGEMENT}

The authors would like to acknowledge the Regional Universities Forum for Capacity Building in Agriculture (RUFORUM) for financing this research under the nurturing grant for female empowerment through postgraduate education at Jimma University. The University is also appreciated for providing access to a facility during the conduct of this research.

\section{SOURCE OF FINANCING}

This study is financed by the Regional Universities Forum for Capacity Building in Agriculture (RUFORUM).

\section{REFERENCES}

AAUW (2015). Gender Equity and the Role of Women in Poland. Retrieved from: https://files.eric.ed.gov/fulltext/ ED557832.pdf

Abebaw, S. (2003). Dimensions and determinants of food security among rural households in Dire Dawa, Eastern Ethiopia. An MSc Thesis Presented to the School of Graduate Studies of Alemaya University.

ACDI/VOCA (2013). Cooperatives Hold Economic Promise for Women in Ethiopia. Feed the Future Program Bolsters Cooperatives as Empowerment Strategy for Women.

Adenew, B. (2004). The food security role of agriculture in Ethiopia. J. Agric. Dev. Econ. 1, 138-153.

Amentae, T. K., Tura, E. G., Gebresenbet, G., Ljungberg, D. (2016). Exploring value chain and post-harvest losses of Teff in Bacho and Dawo districts of central Ethiopia. J. Stored Prod. Postharv. Res., 7(1), 11-28.

Aregu, L., Puskur, R., Bishop-Sambrook, C. (2011). The role of gender in crop value chain in Ethiopia. Retrieved from: https://cgspace.cgiar.org/handle/10568/21037

Arendt, E., Zannini, E. (2013). Cereal Grains for the Food and Beverage Industries. 1st Edition, Woodhead Publishing.

AU (2009). Gender policy. Addis Ababa: African Union.

Ayalew, Y. (2015). Factors affecting fruit supply in the market: The case of habru woerda, North Wollo, Ethiopia. Eur. J. Bus. Manag., 7, 309-318.

Ayelech, T. (2011). Market chain analysis of fruits for Gommaworeda, Jimma zone, Oromia National Regional State. MSc thesis presented to School of Graduate Studies, Haramaya University.

Belachew, T., Hadley, C., Lindstrom, D., Gebremariam, A., Michael, K. W., Getachew, Y., Lachat, C., Kolsteren, P. (2011). Gender differences in food insecurity and morbidity among adolescents in southwest Ethiopia. Pediatrics 127, e398-e405.

Belete, A., Dillon, J. L., Anderson, F. M. (1991). Development of agriculture in Ethiopia since the 1975 land reform. Agric. Econ., 6, 159-175.

BMGF (2010). Accelerating Ethiopian Agriculture Development for Growth, Food Security, and Equity. Bill \& Melinda Gates Foundation (BMGF).

Cochran, W. G. (1977). Sampling Techniques (3rd ed.). New York: Wiley.

Coles, C., Mitchell, J. (2011). Gender and agricultural value chains: A review of current knowledge and practice and their policy implications. ESA Working Paper No. 11-05. Retrieved on June 26, 2017.

CSA (2018). Agricultural sample survey: report on area and production of major crops. The Federal Democratic 
Tekalign, S., Eneyew, A., Mitiku, F. (2020). Gender roles in teff value chain in Borecha District of South Western Ethiopia: husband and wife comparisons. J. Agribus. Rural Dev., 1(55), 93-105. http://dx.doi.org/10.17306/J.JARD.2020.01212

Republic of Ethiopia. Central Statistical Agency 2017/18 (2010 E.C.).

Diao, X., Taffesse, A. S., Yu, B., Pratt, A. N. (2010). Economic importance of agriculture for sustainable development and poverty reduction: The case study of Ethiopia. In "Global forum on agriculture", pp. 29-30.

EC (2018). 2018 Report on equality between women and men in the European Union. European Commission.

Fakoya, E., Agbonlahor, M., Dipeolu, A. (2007). Attitude of women farmers towards sustainable land management practices in South-Western Nigeria. World J. Agric. Sci., 3, 536-542.

Fletschner, D., Kenney, L. (2014). Rural women's access to financial services: credit, savings, and insurance. In: Gender in agriculture (pp. 187-208). Netherlands: Springer.

Gammage, S., Manfre, C., Cook, K. (2009). Gender and Pro-Poor Value Chain Analysis: Insights from the GATE project methodology and case studies. Washington DC: USAID.

Gujarati, D. N. (2009). Basic econometrics. Tata McGrawHill Education.

Hansen, C. W., Jensen, P. S., Skovsgaard, C. V. (2015). Modern gender roles and agricultural history: the Neolithic inheritance. J. Econ. Growth, 20, 365-404.

Hauenstein, S. (2015). Assessing the resilience of the tef value chain in Ethiopia. Zurich, Switzerland: Swiss Federal Institute of Technology Zurich, ETH. Department of Environmental Systems Science, and Chair of Sustainable Agro-Ecosystems.

Haymanot, A. (2014). Durum Wheat Value Chain Analysis: The Case of Gololcha District Of Bale Zone. Ethiopia Haramaya University.

Jauch, H. (2002). Export processing zones and the quest for sustainable development: a Southern African perspective. Env. Urb., 14, 101-113.

Kaplinsky, R., Morris, M. (2000). A handbook for value chain research. Brighton: University of Sussex, Institute of Development Studies.

Lal, R., Khurana, A. (2011). Gender issues: The role of women in agriculture sector. Int. J. Business Econ. Manag. Res., 1, 29-39.

Leach, M. (2015). Gender equality and sustainable development. Routledge.

Leopold, T. A., Ratcheva, V., Zahidi, S. (2016). The global gender gap report 2016. World Economic Forum.

Meinzen-Dick, R., Behrman, J., Menon, P., Quisumbing, A. (2012). Gender: A key dimension linking agricultural programs to improved nutrition and health. Reshaping agriculture for nutrition and health (pp. 135-144).

Minten, B., Tamru, S., Engida, E., Kuma, T. (2013). Ethiopia's value chain on the move: the case of teff. Ethiopia: Strategy Support Program II.

MoWA (2005). Gender Relations in Ethiopia: Final Report. Addis Ababa, Ethiopia: Ministry of Women's Affairs (MoWA).

Mutua, E., Njuki, J., Waithanji, E. (2014). Review of gender and value chain analysis, development and evaluation toolkits. Retrieved from: https://cgspace.cgiar.org/ handle/10568/35656

Ogato, G., Boon, E., Subramani, J. (2009). Gender roles in crop production and management practices: a case study of three rural communities in Ambo district, Ethiopia. J. Human Ecol., 27, 1-20.

Raney, T., Anríquez, G., Croppenstedt, A., Gerosa, S., Lowder, S. K., Matuschke, I., Skoet, J. (2011). The role of women in agriculture. ESA Working Papers, FAO.

Rathgeber, E. M. (1990). WID, WAD, GAD: Trends in research and practice. J. Dev. Areas, 24, 489-502.

Rehima, M. (2006). Analysis of Red pepper marketing: the case of Alaba and Silte in SNNPRS. MSc thesis presented to the school of graduate studies of Haramaya University, Ethiopia.

Tadesse, A. (2011). Market chain analysis of fruits for Gomma woreda, Jimma zone. Alemaya: Oromia National Regional State, Haramaya University.

Tura, E. G., Goshub, D., Demise, T., Kenead, T. (2016). Determinants of market participation and intensity of marketed surplus of Teff producers in Bacho and Dawo districts of Oromia state, Ethiopia. Forthcoming: Agricultural Economics.

Urquieta, A., Rosa, N. (2009). Effects of access to information on farmer's market channel choice: The Case of Potato in Tiraque Sub-watershed (Cochabamba-Bolivia). Virginia Tech.

Uzodike, U. O., Onapajo, H. (2013). Women and Development in Africa: Competing Approaches and Contested Achievements. Alternation, 20(2), 27-51.

Van De Vijver, F. J. (2007). Cultural and gender differences in gender-role beliefs, sharing household task and childcare responsibilities, and well-being among immigrants and majority members in the Netherlands. Sex Roles, 57, 813-824. 